\title{
DESCRIPTION OF PIEZOMETERS INSTALLED IN THE DURANES WELL FIELD AREA, ALBUQUERQUE, NEW MEXICO
}

By Condé R. Thorn

\section{U.S. GEOLOGICAL SURVEY}

Open-File Report 98-415

Prepared in cooperation with the OFFICE OF THE STATE ENGINEER 


\title{
U.S. DEPARTMENT OF THE INTERIOR BRUCE BABBITT, Secretary
}

\author{
U.S. GEOLOGICAL SURVEY
}

Thomas J. Casadevall, Acting Director

The use of firm, trade, and brand names in this report is for identification purposes only and does not constitute endorsement by the U.S. Geological Survey.

For additional information write to:

District Chief

U.S. Geological Survey Water Resources Division 4501 Indian School Road NE, Suite 200 Albuquerque, NM 87110-3929
Copies of this report can be purchased from:

U.S. Geological Survey Branch of Information Services Box 25286

Denver, CO 80225-0286 


\section{CONTENTS}

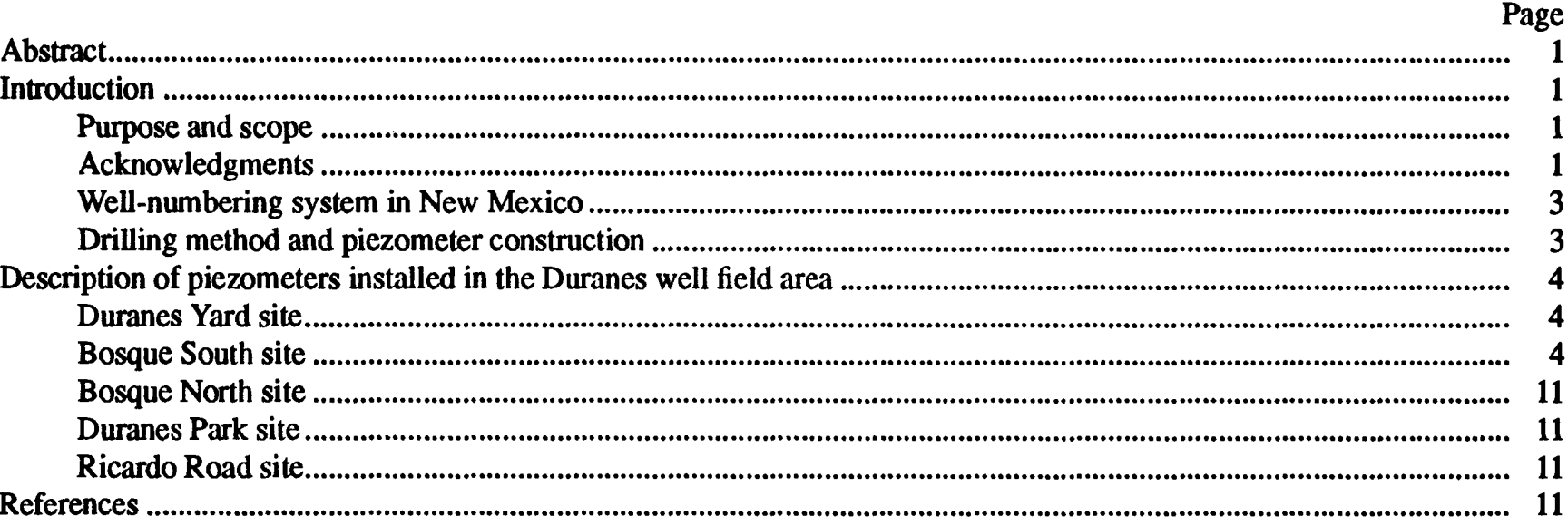

\section{FIGURES}

1. Map showing location of piezometer sites and City of Albuquerque production wells in the

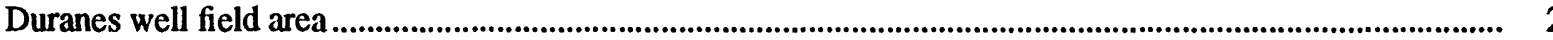

2. Diagram showing well-numbering system in New Mexico................................................................................... 3

3. Diagram showing configuration of piezometers at the piezometer sites in the Duranes well field area, Albuquerque, New Mexico

4-8. Diagrams showing lithologic and geophysical logs and piezometer completion diagram for the:
4. Duranes Yard site
5. Bosque South site
6. Bosque North site
7. Duranes Park site.
8. Ricardo Road site

\section{TABLE}

1. Location, construction information, and initial water-level data for piezometers installed in the Duranes well field area.

CONVERSION FACTORS AND VERTICAL DATUM

\begin{tabular}{lccl}
\hline & Bultiply & To obtain & millimeter \\
\hline & inch & 25.40 & meter \\
foot & 0.3048 & kilometer \\
& mile & 1.609 & square meter \\
\hline
\end{tabular}




\title{
DESCRIPTION OF PIEZOMETERS INSTALLED IN THE DURANES WELL FIELD AREA, ALBUQUERQUE, NEW MEXICO
}

\author{
By Condé R. Thorn
}

\section{Abstract}

Since 1993, the aquifer system in the Middle Rio Grande Basin, and particularly in the Albuquerque area, has been the focus of studies to further define the extent of the most productive parts of the aquifer and to gain a better understanding of ground-water/surface-water interactions. Twenty-one piezometers were installed during January and February 1997 at five sites in the Duranes well field area in Albuquerque, New Mexico, to allow for concentrated collection of hydraulic-head data. This concentrated collection of shallow hydraulichead data may lead to a better understanding of the effects of ground-water production on the Rio Grande near a City of Albuquerque well field.

Each piezometer was installed in a hole augered by a rig using hollow-stem auger flights. All piezometers are constructed of flush-joint polyvinyl chloride casing with 5-foot polyvinyl chloride screens. The uppermost 2 feet of the piezometer casing is covered by a steel casing with a locking lid. Driller's logs and geophysical logs were collected from the deepest hole and piezometer, respectively, at each site. This report describes the piezometers installed and presents initial water-level data for all piezometers.

\section{INTRODUCTION}

Since 1993, the aquifer system of the Middle Rio Grande Basin, and particularly in the Albuquerque area, has been the focus of many studies to further define the extent of the most productive parts of the aquifer and to gain a better understanding of groundwater/surface-water interactions (Hawley and Haase, 1992; Thorn and others, 1993; Kernodle and others, 1995; McAda, 1996). During January and February 1997, the U.S. Geological Survey (USGS), in cooperation with the Office of the State Engineer, installed 21 piezometers at five sites in the Duranes well field area, Albuquerque, New Mexico. The piezometers will allow for the collection of concentrated shallow hydraulic-head data along the Rio Grande near the City of Albuquerque municipal well field known as the Duranes well field. This concentrated collection of shallow hydraulic-head data may lead to a better understanding of the effects of ground-water production on the Rio Grande near a City of Albuquerque well field. This report was prepared in cooperation with the Office of the State Engineer.

\section{Purpose and Scope}

This report describes a series of piezometers that were installed along the Rio Grande near the Duranes well field (fig. 1). The report includes configuration of the piezometers at each site, lithologic and geophysical logs at each site, drilling methods, completion diagrams of all piezometers, and initial water-level data for all piezometers.

\section{Acknowledgments}

The author thanks personnel of the Middle Rio Grande Conservancy District for permission to install the piezometers on the Ricardo Road site; personnel of the New Mexico Highway and Transportation Department for permission to install the piezometers on the North Bosque site; personnel of the Open Space Division, City of Albuquerque; and City of Albuquerque water managers for granting permission to install the piezometers on the remaining three sites. Without the cooperation of these individuals, the piezometer installation would not have been successful. 

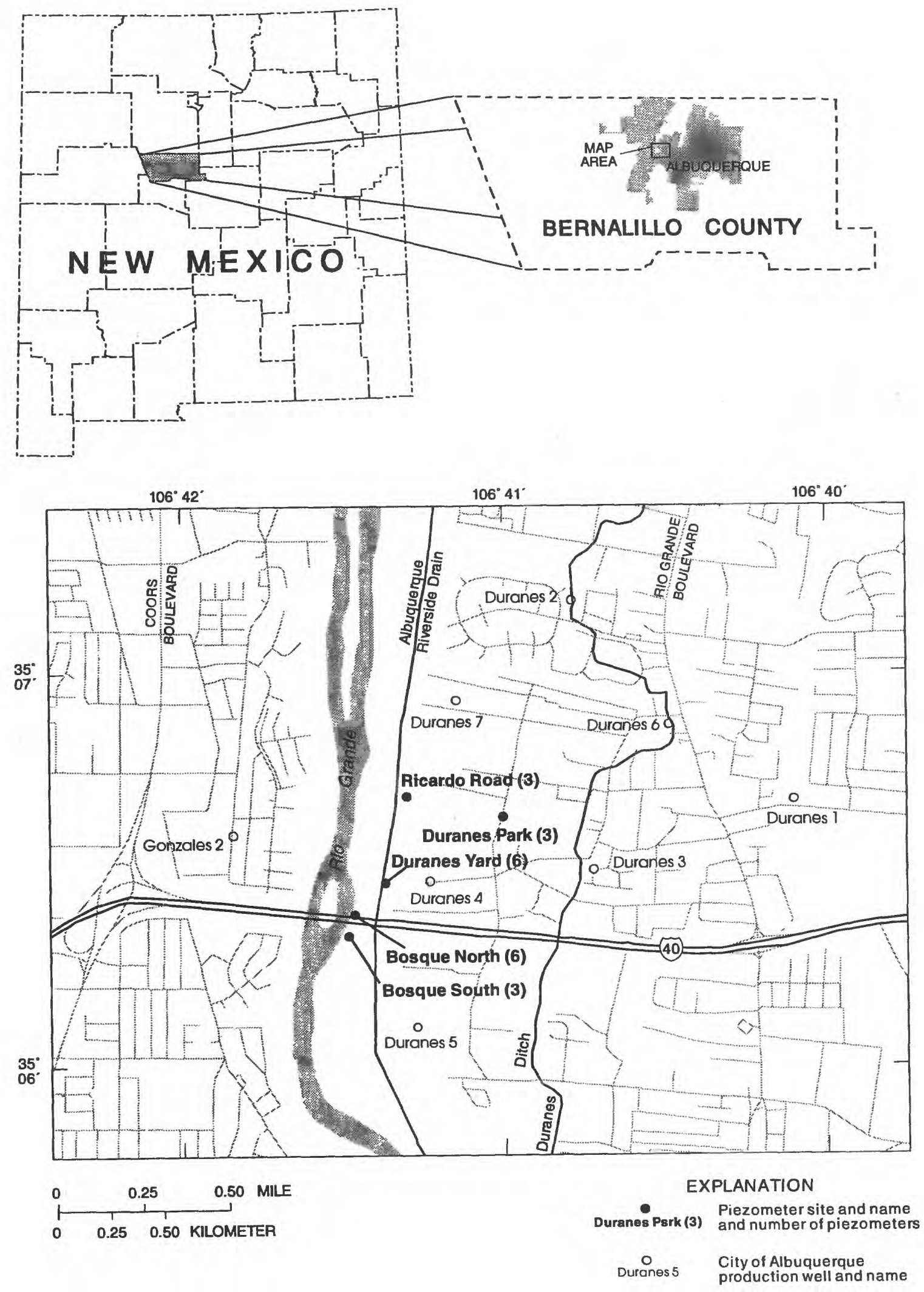

Figure 1.--Location of piezometer sites and City of Albuquerque production wells in the Duranes well field area. 


\section{Well-Numbering System in New Mexico}

The system of numbering wells in New Mexico is based on the common subdivision of public lands into sections (fig. 2). The well number, in addition to designating the well, locates its position to the nearest 10 -acre tract in the land network. This number is divided into four segments. The first segment denotes the township north (N.) or south (S.) of the New Mexico base line, the second denotes the range east (E.) or west (W.) of the New Mexico principal meridian, and the third denotes the section. The fourth segment of the number, which consists of three digits, denotes the 160-, 40-, and 10-acre tracts, respectively, in which the well is situated. For this purpose, the section is divided into four quarters, numbered 1, 2, 3, and 4 , for the northwest, northeast, southwest, and southeast quarters, respectively. The first digit of the fourth segment denotes the quarter section, which is a tract of 160 acres. Similarly, the quarter section is divided into four 40-acre tracts numbered in the same manner, and the second digit denotes the 40-acre tract. Finally, the 40 -acre tract is divided into four 10 -acre tracts, and the third digit denotes the 10-acre tract. For example, well 10N.02E.12.312 is in the NE $1 / 4$ of the NW $1 / 4$ of the SW $1 / 4$ of section $12, T .10$ N., R. 02 E. (fig. 2). Letters A, B, C, and so on are added to the last segment of the well number to designate the second, third, fourth, and succeeding wells in the same 10-acre tract.

\section{Drilling Method and Piezometer Construction}

A two-person crew from the USGS Central Region drilling program installed the 21 piezometers during January and February 1997. The holes were augered using a CME 85 auger rig with hollow-stem auger flights. One hole was augered for each piezometer; the deepest hole was augered first and the shallowest hole was augered last at each site. After each hole was augered to the targeted depth, flush-joint polyvinyl chloride (PVC) casing was installed inside the hollow-stem auger flights. The PVC casing was used to punch out a small knockout plate located on the

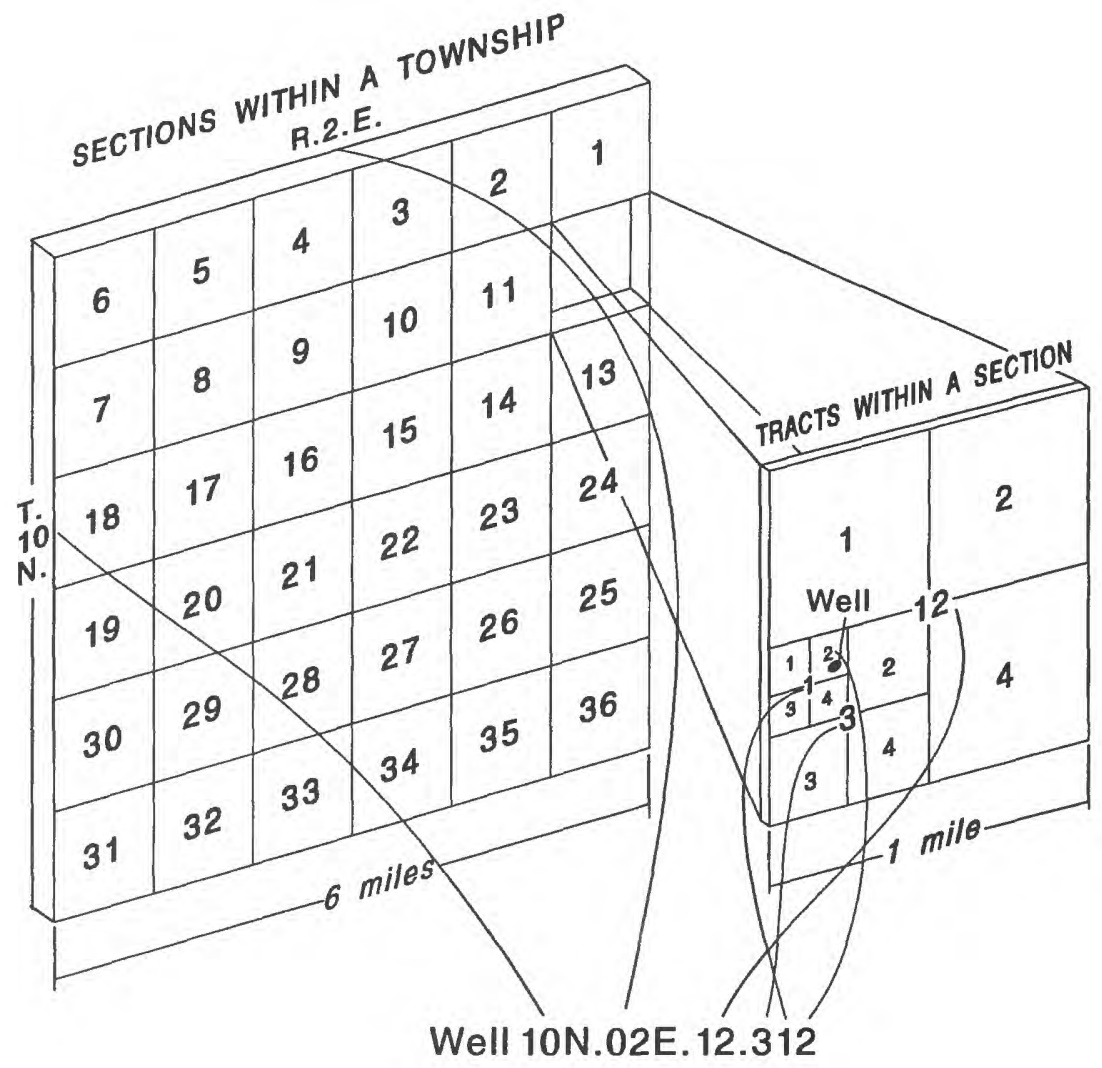

Figure 2.--Well-numbering system in New Mexico. 
bottom of the lowermost auger flight. The knockout plate prevented material from entering the hole as the auger flights rotated downward through the unconsolidated material. Removal of the knockout plate allowed the backfilling material, which was poured or pumped down the inside of the auger flights, to spill out the bottom of the auger flights and fill the annular space between the PVC casing and the borehole wall as the auger flights were backed out of the hole in 5-foot sections. A primary filter pack (backfill material in the annular space surrounding and immediately above the screen) of 10-20 silica sand was placed in the annulus to about 2-5 feet above the top of the screen. Ten-twenty silica sand has an intermediate axis between 0.0331 and 0.0787 inch (between 0.841 and 2 millimeters). The amount of 10-20 silica sand used depended on the degree to which the borehole wall caved in (providing for a natural primary filter pack). Bentonite grout (EP grout containing 30percent solids) was pumped down a tremie pipe (a small-diameter pipe used to conduct material to the bottom of a hole) to fill the annular space from the top of the primary filter pack to a depth of about 2 feet below land surface. A driller's log was obtained from the deepest hole at each site, and geophysical logs were run inside the completed piezometer after all the backfilling material was placed in the annulus of the deepest piezometer.

Once all piezometers were installed at each site, a rectangular steel casing protector, with locking lid, was cemented into the ground covering each piezometer. A centrally located recorder shelter also was installed to house a data logger and power supply (fig. 3). Flexible conduit was buried between each piezometer and the recorder shelter so that wiring from pressure transducers installed later could be fed from all piezometers to the recorder shelter. Before the auger rig moved off site, all piezometers were bailed to remove any fine-grained material that might have passed through the screen during backfilling of the annulus. Bailing continued on each piezometer until no fine-grained material was present.

All piezometers are constructed of schedule- 40 PVC pipe with an inner diameter of about 2 inches. Each piezometer has a lowermost 5-foot section of blank PVC pipe that is capped on the bottom. Above this pipe is a 5-foot section of PVC screen with a slot size of about 0.010 inch. Above the screen is blank PVC casing that extends about 2 feet above land surface. All piezometers have a 12 - to 15 -foot-thick primary filter pack. Each piezometer's rectangular steel casing protector protrudes about 4 feet above land surface.

\section{DESCRIPTION OF PIEZOMETERS INSTALLED IN THE DURANES WELL FIELD AREA}

\section{Duranes Yard Site}

The Duranes Yard site is within a fenced-in area that also encompasses a City of Albuquerque municipal well (Duranes 4) and a pump house. The Duranes Yard site consists of six piezometers; the top of the screened intervals ranges from 7.0 to 95.0 feet below land surface (table 1). In addition to the six piezometers, one in situ permeable flow sensor was installed in a hole augered to about 22 feet. This flow sensor allows direct measurement of the threedimensional ground-water-flow velocity vector in unconsolidated, saturated, porous material (Ballard, 1996). The configuration of the piezometers and flow sensor at the site is displayed in figure 3. Lithologic and geophysical logs and a piezometer completion diagram for the Duranes Yard site are displayed in figure 4. Table 1 lists piezometer locations, identification numbers, construction information, and initial waterlevel data.

\section{Bosque South Site}

The Bosque South site is located south of Interstate 40 on the east bank of the Rio Grande (fig. 1). This site has three piezometers; the top of the screened intervals ranges from 9.7 to 86.3 feet below land surface (table 1). The configuration of the piezometers at the site is displayed in figure 3. Lithologic and geophysical logs and a piezometer completion diagram are displayed in figure 5. Table 1 lists piezometer locations, identification numbers, construction information, and initial water-level data. 


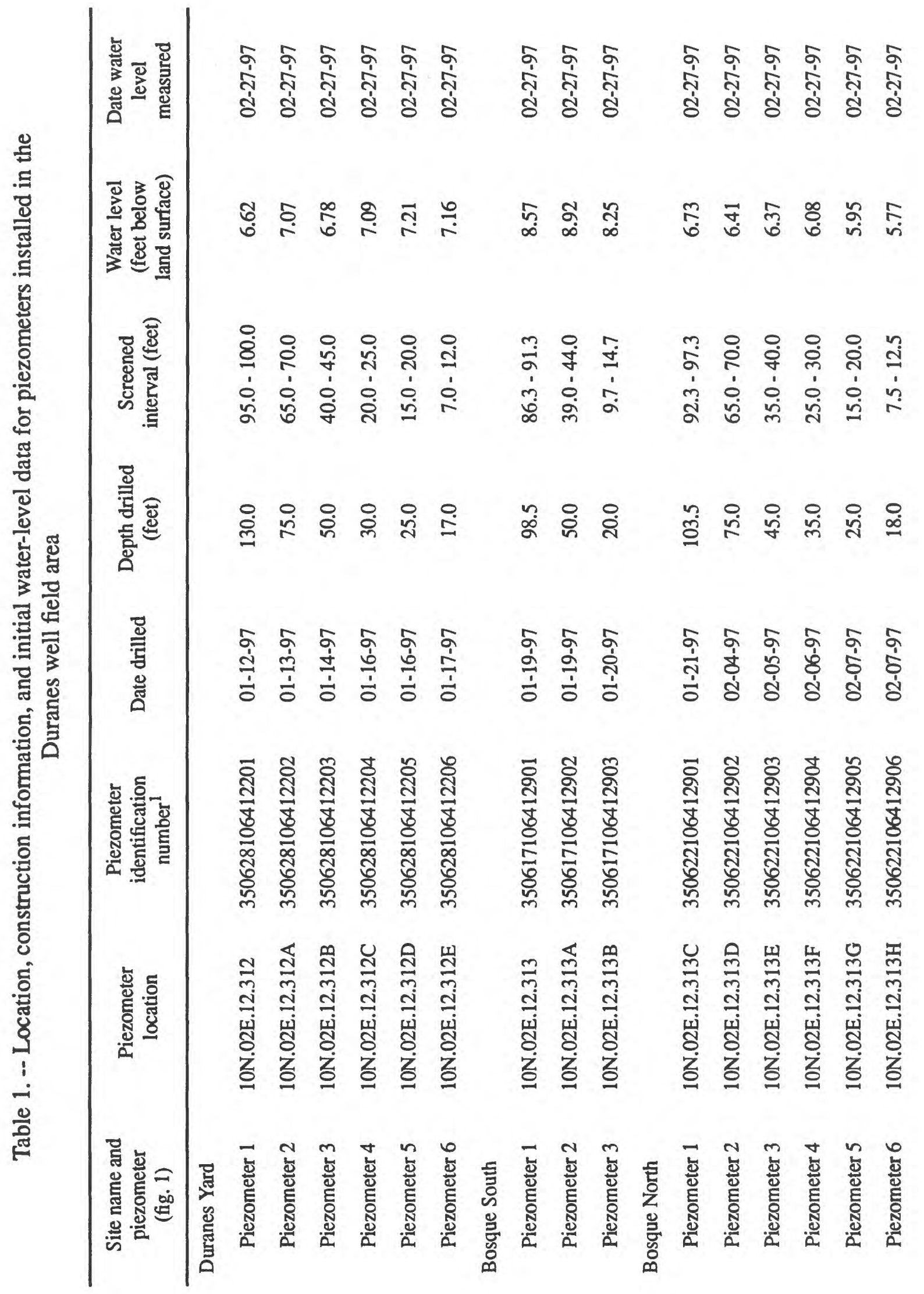




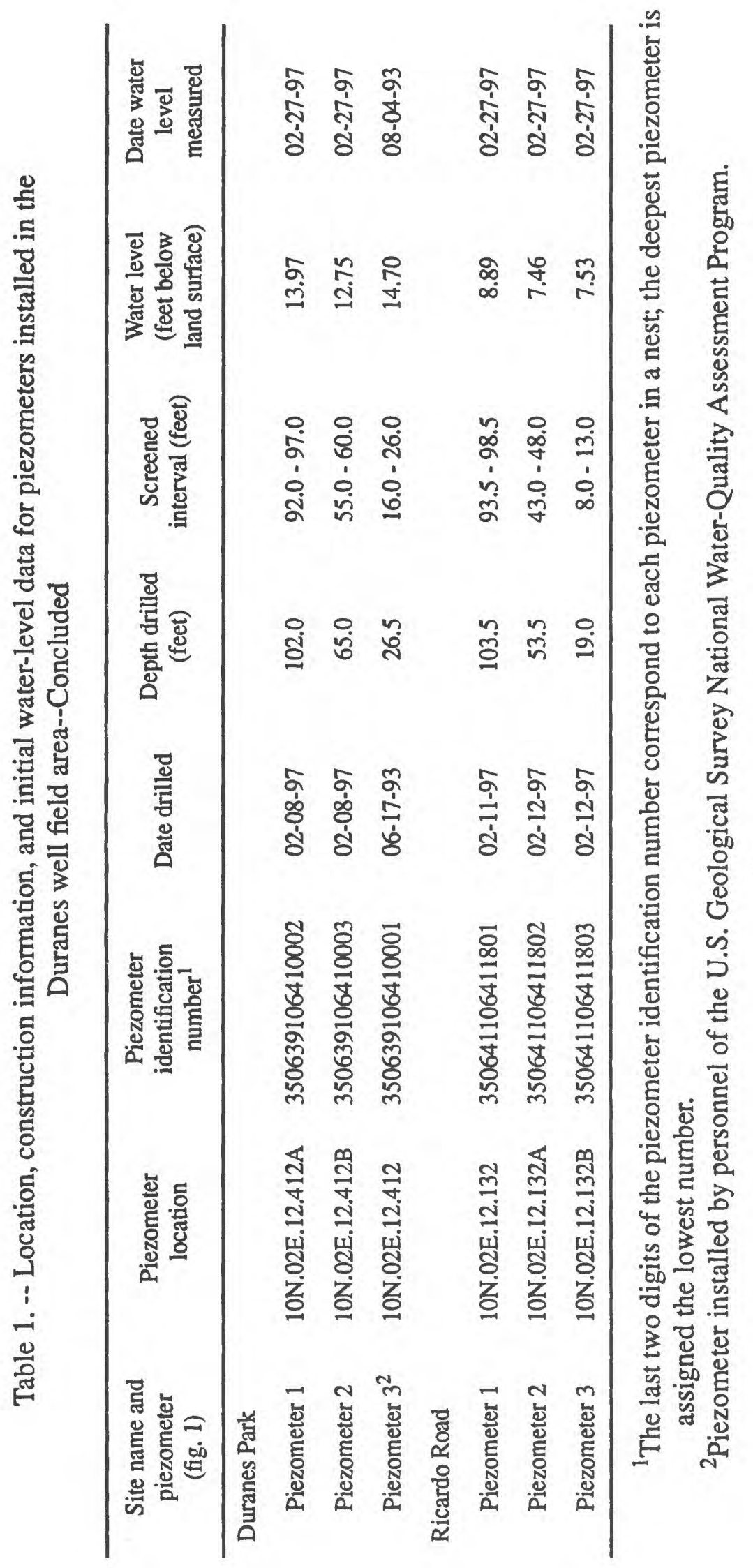




\section{Duranes Yard site}
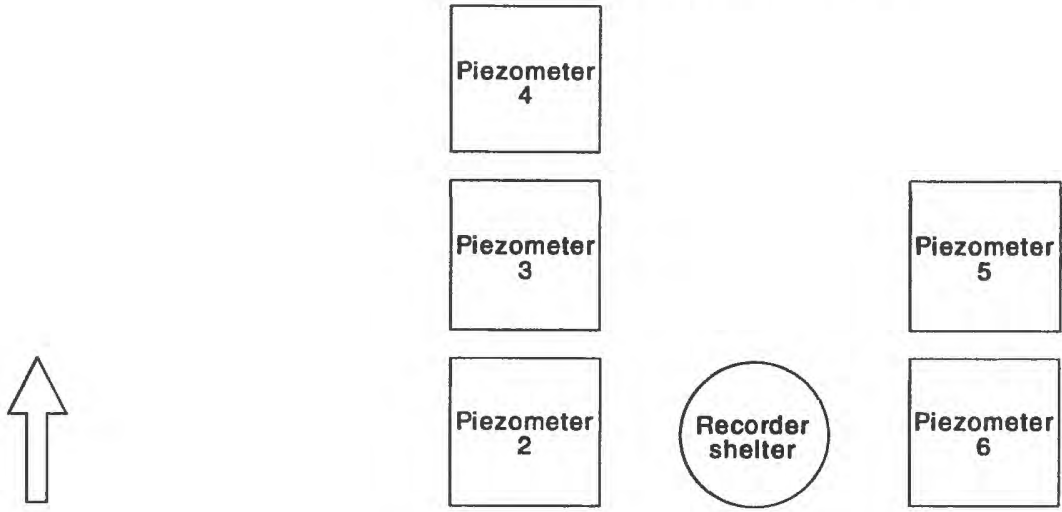

$\mathrm{N}$
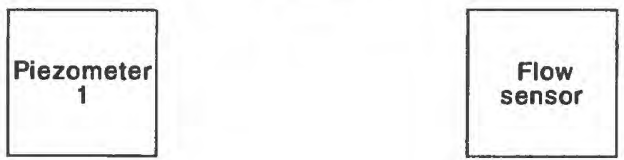

$\mathrm{H}$

\section{Bosque South site}
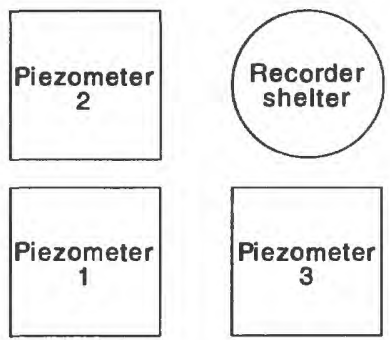

NOT TO SCALE
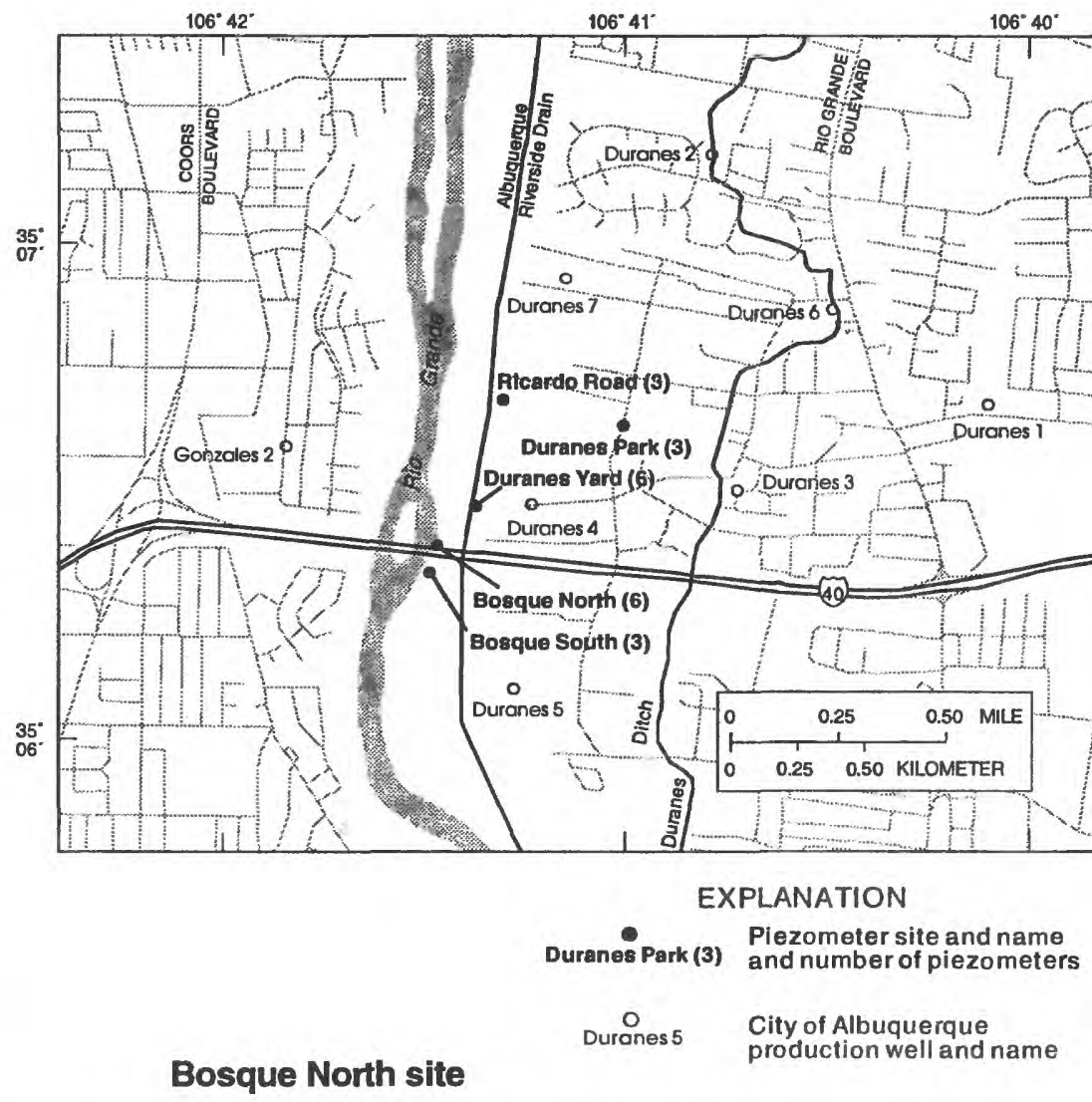

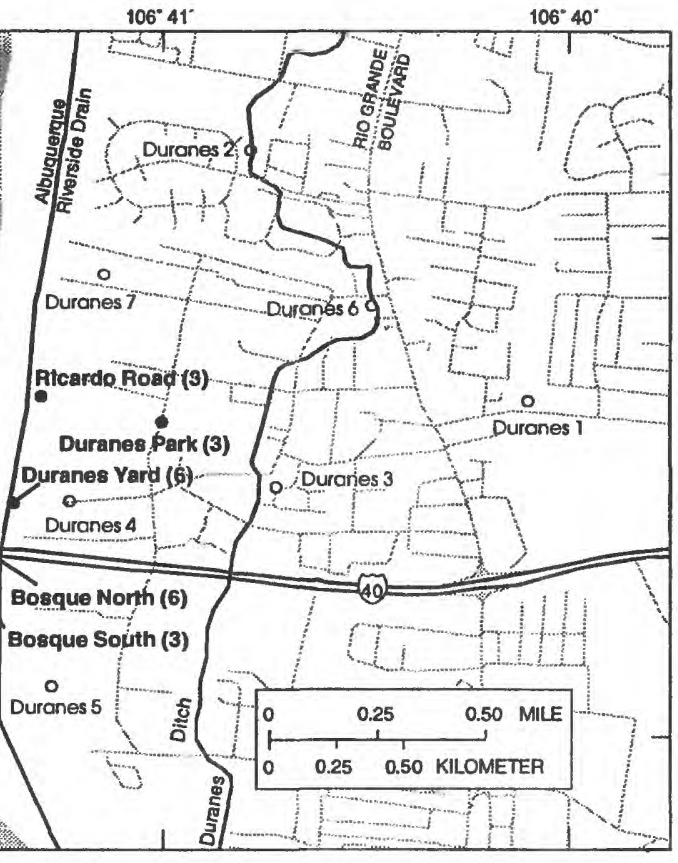

\section{EXPLANATION}

and number of piezometers

production well and name
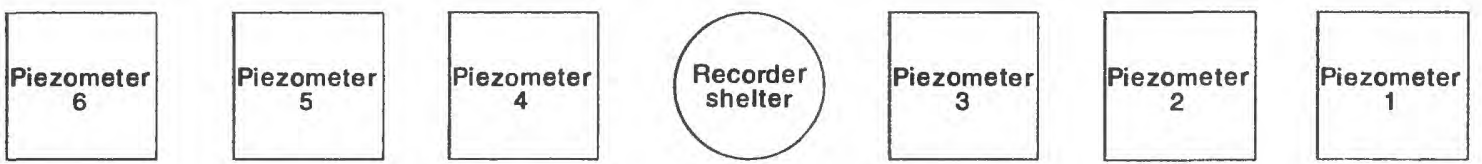

Figure 3.--Configuration of piezometers at the piezometer sites in the Duranes well field area, Albuquerque, New Mexico. 


\section{Duranes Park site}

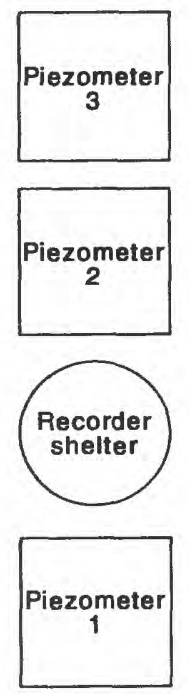

\section{Note: Piezometer 3 at the Duranes Park site was installed by personnel of the Rio Grande Valley study unit of the U.S. Geological Survey National Water-Quality Assessment Program.}

\section{Ricardo Road site}
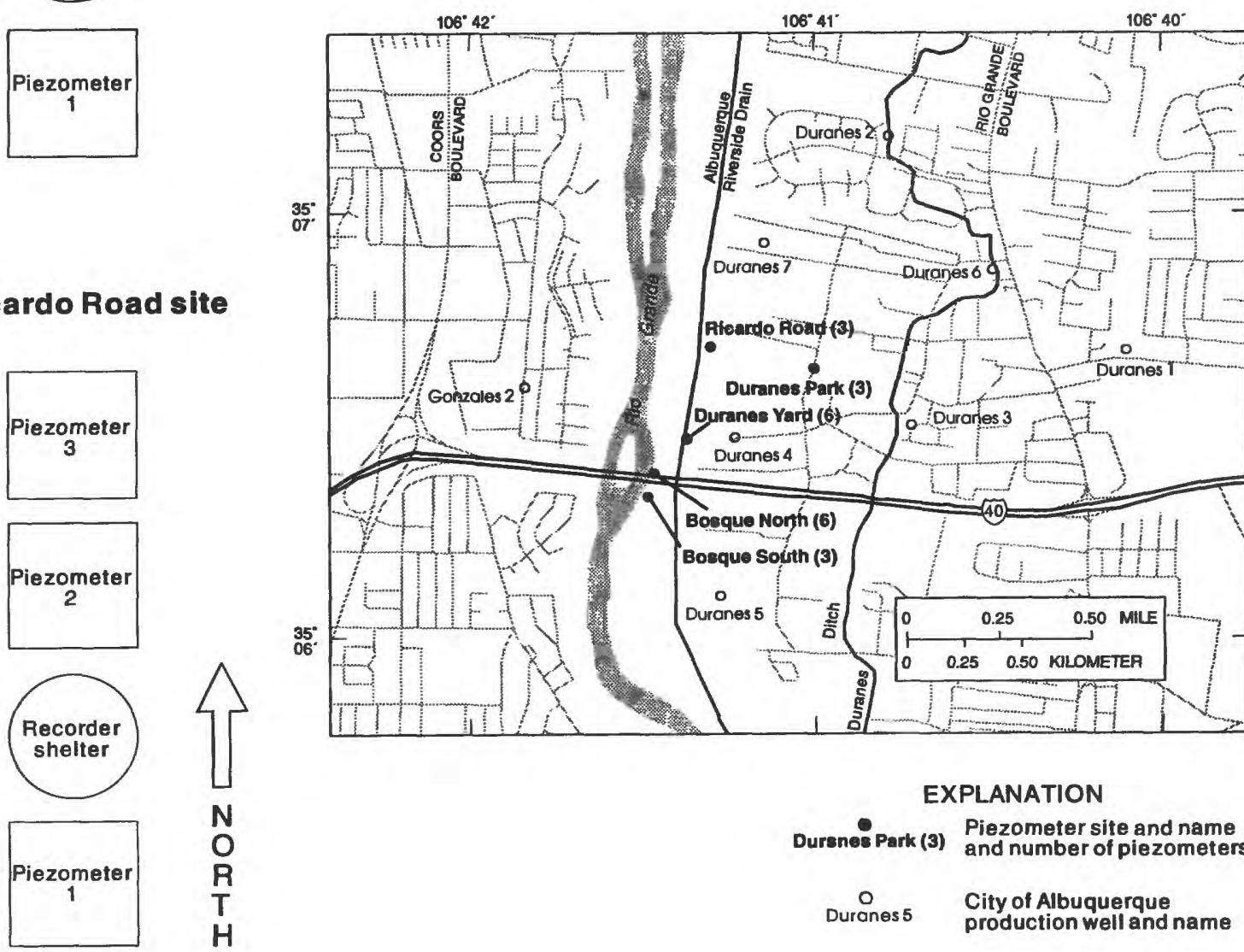

$\mathbf{N}$
$\mathrm{O}$
$\mathrm{R}$
$\mathrm{T}$
$\mathrm{H}$

\section{EXPLANATION}

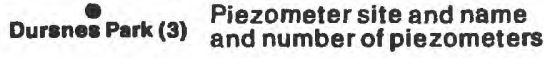
$\stackrel{\circ}{\text { Duranes } 5}$

City of Albuquerque production well and name

NOT TO SCALE

Figure 3.--Configuration of piezometers at the piezometer sites in the Duranes well field area, Albuquerque, New Mexico--Concluded. 


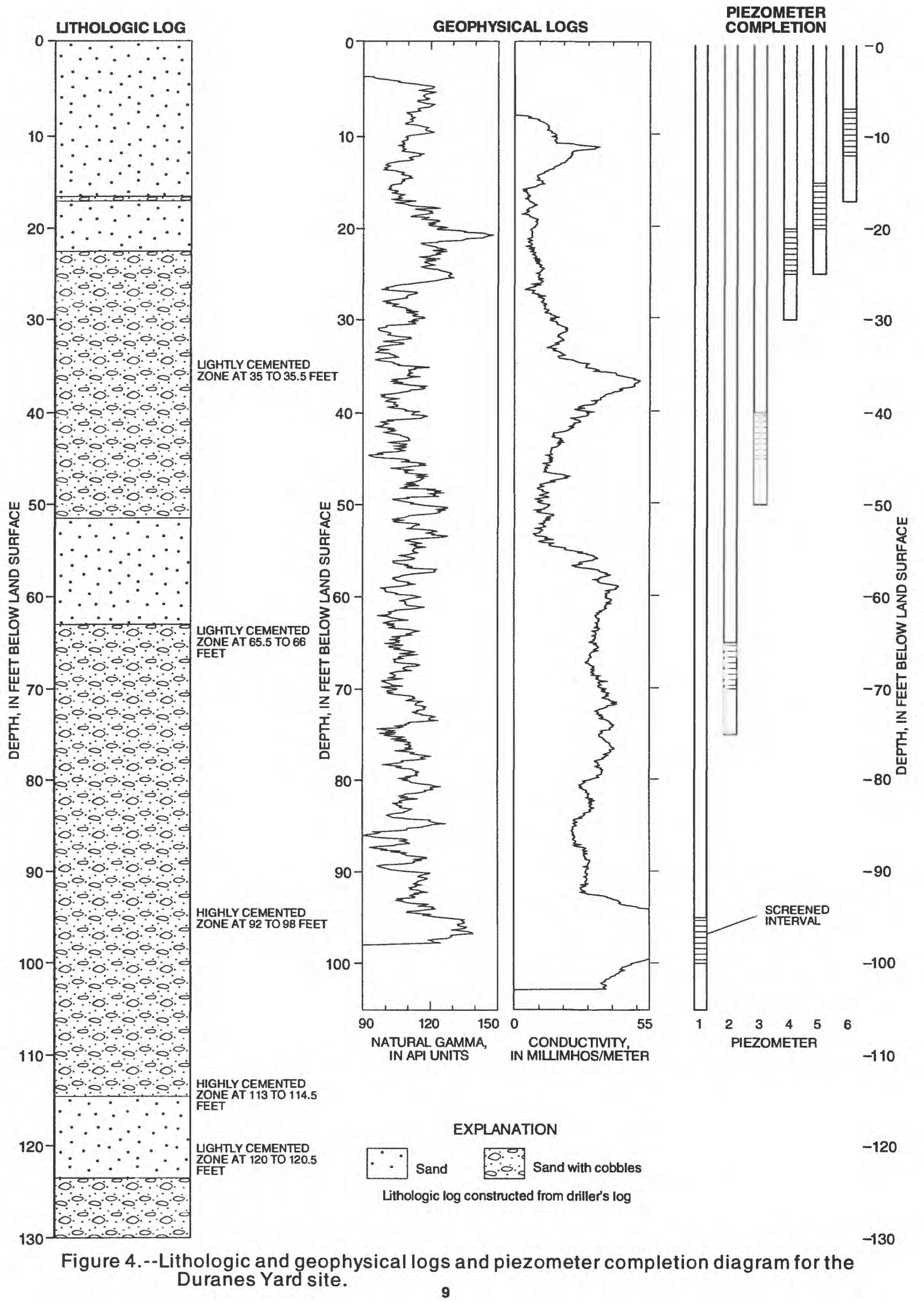



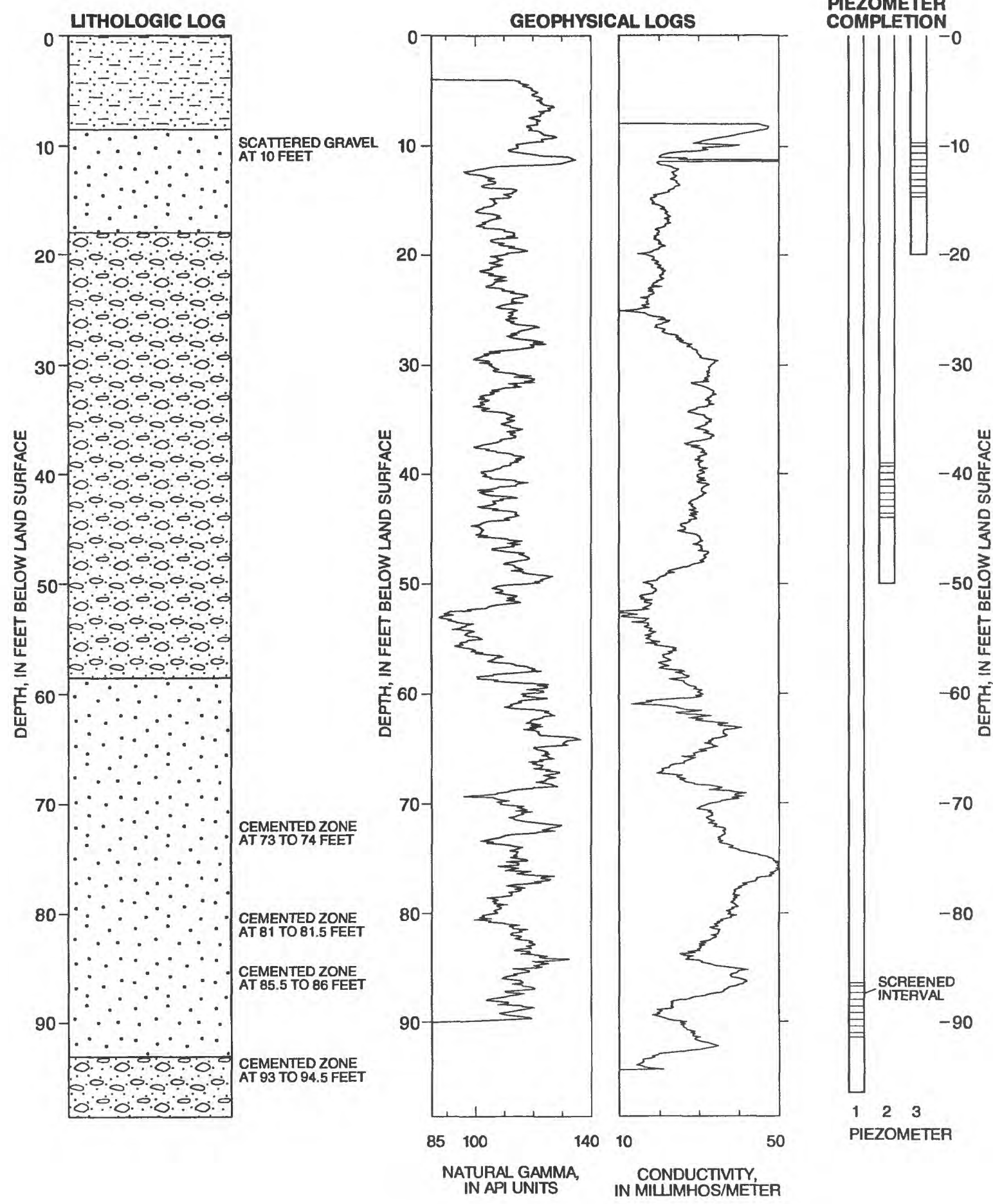

EXPLANATION

Silty sand $\because \because$ Sand $\quad$ Sand with gravel and/or cobbles Lithologic log constructed from driller's log

Figure 5.--Lithologic and geophysical logs and piezometer completion diagram for the Bosque South site. 


\section{Bosque North Site}

The Bosque North site is located north of Interstate 40 on the east bank of the Rio Grande (fig. 1). The site consists of six piezometers; the top of the screened intervals ranges from 7.5 to 92.3 feet below land surface (table 1). The configuration of the piezometers at the site is displayed in figure 3 .

Lithologic and geophysical logs and a piezometer completion diagram are displayed in figure 6. Table 1 lists piezometer locations, identification numbers, construction information, and initial waterlevel data.

\section{Duranes Park Site}

The Duranes Park site is located in Los Duranes Park and is the easternmost of the five sites (fig. 1). The site consists of two piezometers drilled for this study and a piezometer that was installed in June 1993 by personnel of the Rio Grande Valley study unit of the USGS National Water-Quality Assessment Program. The top of the screened intervals ranges from 16.0 to 92.0 feet below land surface (table 1). The configuration of all three piezometers at the site is displayed in figure 3. Lithologic and geophysical logs and a piezometer completion diagram for the two piezometers installed during the present study are displayed in figure 7. Table 1 lists piezometer locations, identification numbers, construction information, and initial water-level data.

\section{Ricardo Road Site}

The Ricardo Road site is located just east of the Albuquerque Riverside Drain and is the northernmost of the five sites (fig. 1). The site consists of three piezometers; the top of the screened intervals ranges from 8.0 to 93.5 feet below land surface (table 1). The configuration of the piezometers at the site is displayed in figure 3. Lithologic and geophysical logs and a piezometer completion diagram are displayed in figure 8. Table 1 lists piezometer locations, identification numbers, construction information, and initial waterlevel data.

\section{REFERENCES}

Ballard, S.B., 1996, The in situ permeable flow sensor--A tool for monitoring 3D groundwater flow velocity: Hydro Technics, 17 p. (accessed December 30, 1997, at URL http://www.hydrotechnics.com/flowsensors/).

Hawley, J.W., and Haase, C.S., 1992, Hydrogeologic framework of the northern Albuquerque Basin: Socorro, New Mexico Bureau of Mines and Mineral Resources Open-File Report 387, p. IX-7.

Kemodle, J.M., McAda, D.P., and Thorn, C.R., 1995, Simulation of ground-water flow in the Albuquerque Basin, central New Mexico, 1901-1994, with projections to 2020: U.S. Geological Survey WaterResources Investigations Report 94-4251, 114 p.

McAda, D.P., 1996, Plan of study to quantify the hydrologic relations between the Rio Grande and the Santa Fe Group aquifer system near Albuquerque, central New Mexico: U.S. Geological Survey Water-Resources Investigations Report 96-4006, 58 p.

New Mexico State Engineer Office, 1996, Proposed hydrologic studies for the Middle Rio Grande Valley, fiscal year 1997: New Mexico State Engineer Office, 27 p.

Thorn, C.R., McAda, D.P., and Kernodle, J.M., 1993, Geohydrologic framework and hydrologic conditions in the Albuquerque Basin, central New Mexico: U.S. Geological Survey Water-Resources Investigations Report 93-4149, 106 p. 

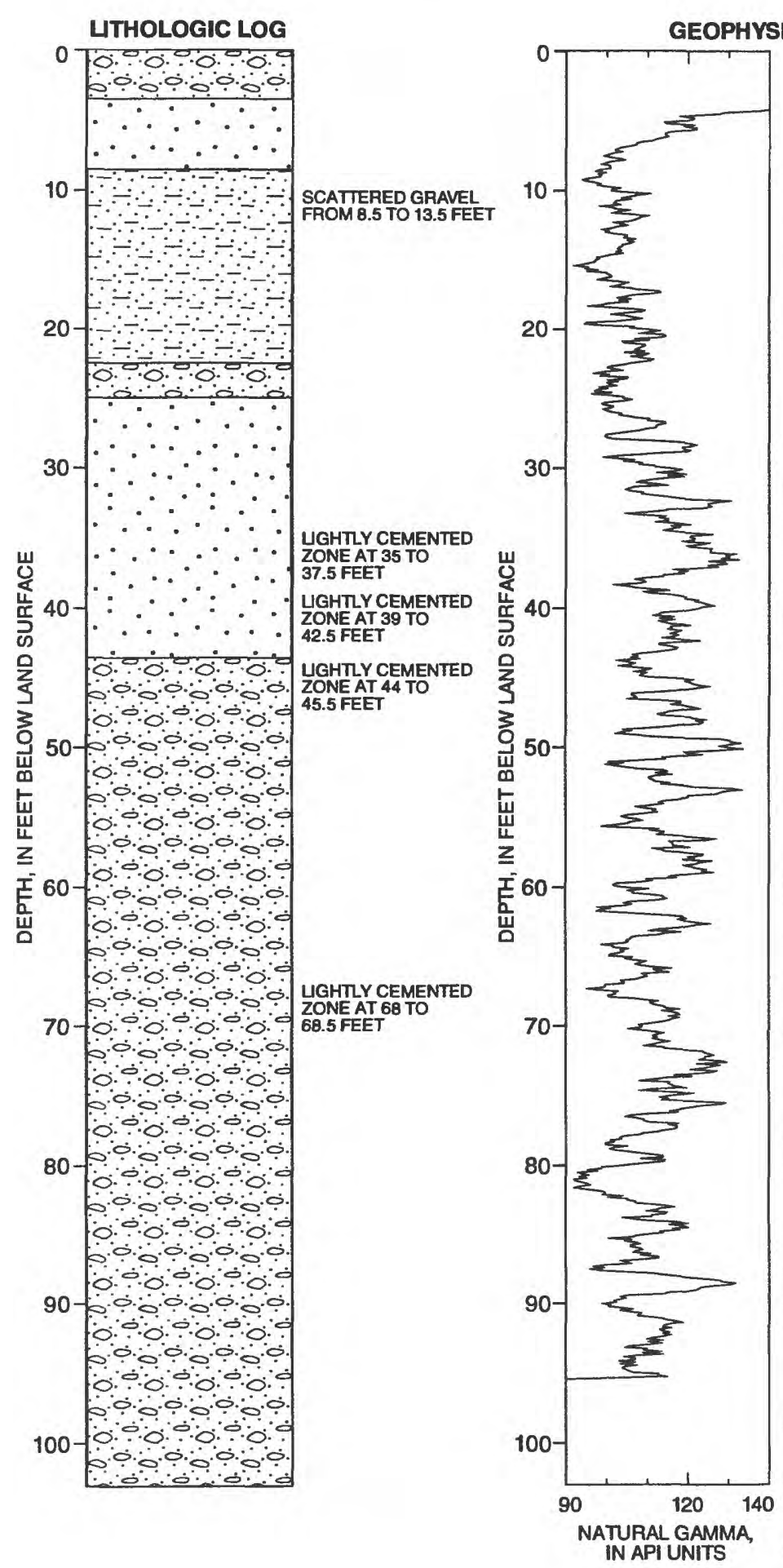
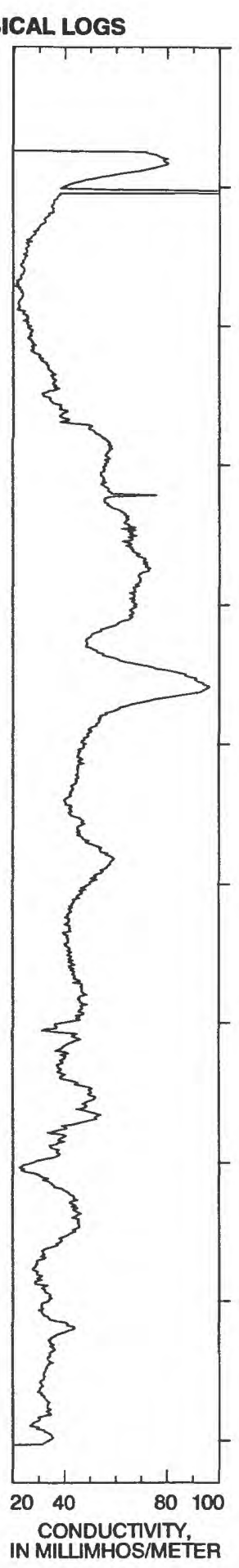

EXPLANATION
PIEZOMETER COMPLETION

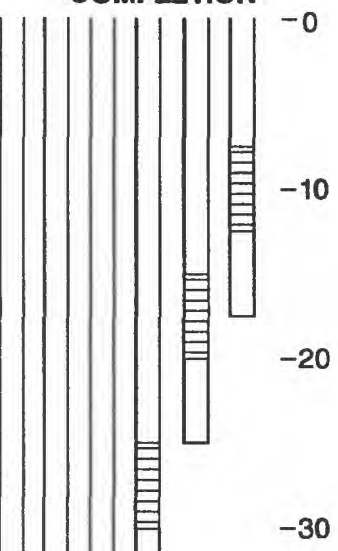

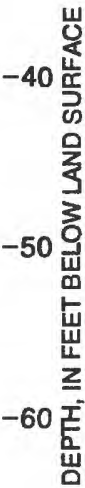

$-70$

$-80$

$-90$ SCREENED
INTERVAL

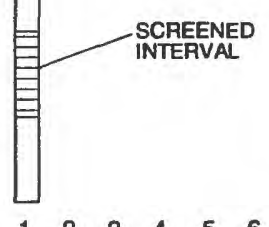

$-100$

Silty sand $\quad[\because$ Sand $\quad 4.0$ Sand with gravel and /or cobbles

Lithologic log constructed from driller's log

Figure 6.--Lithologic and geophysical logs and piezometer completion diagram for the Bosque North site. 

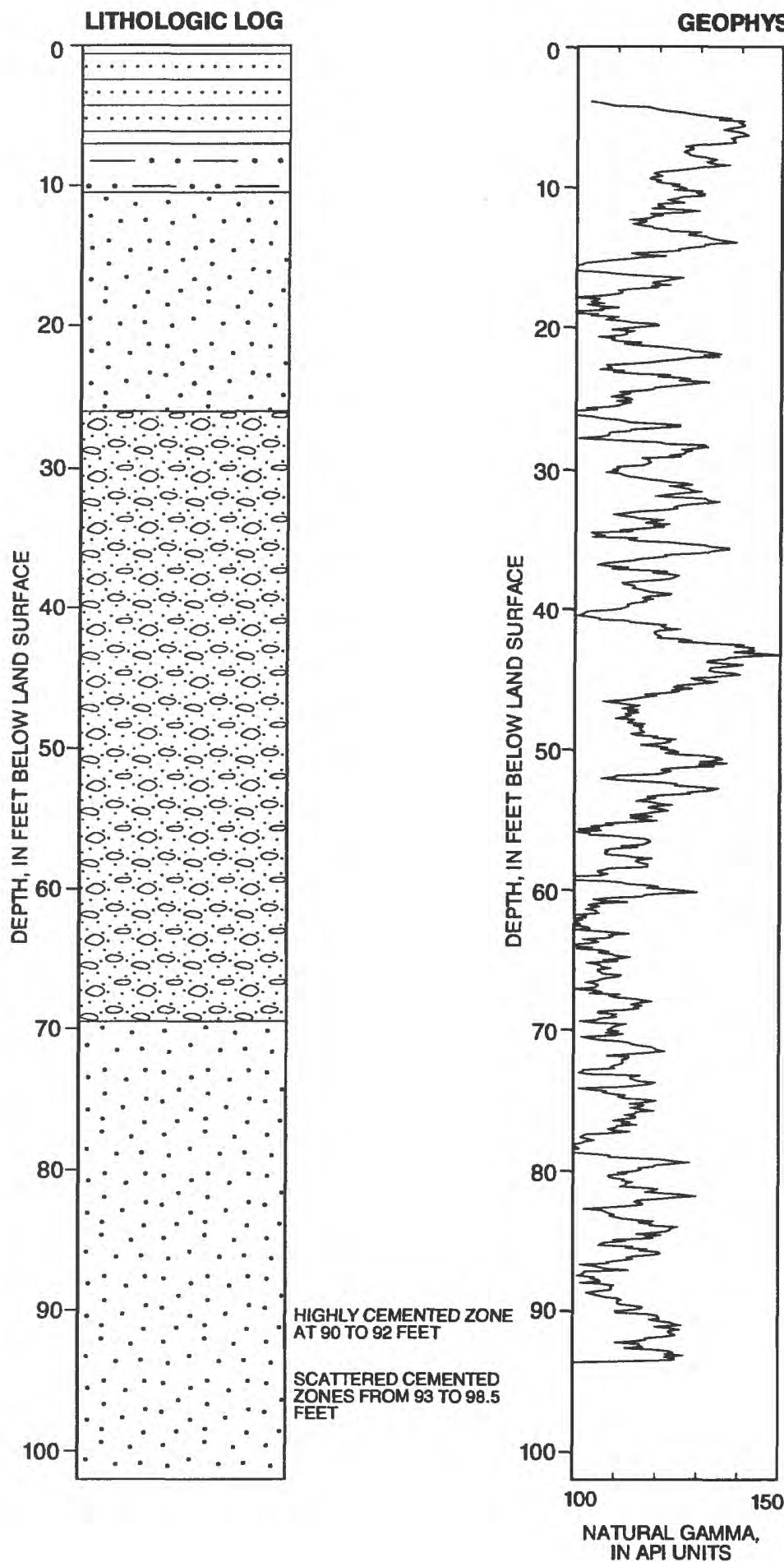

ICAL LOGS

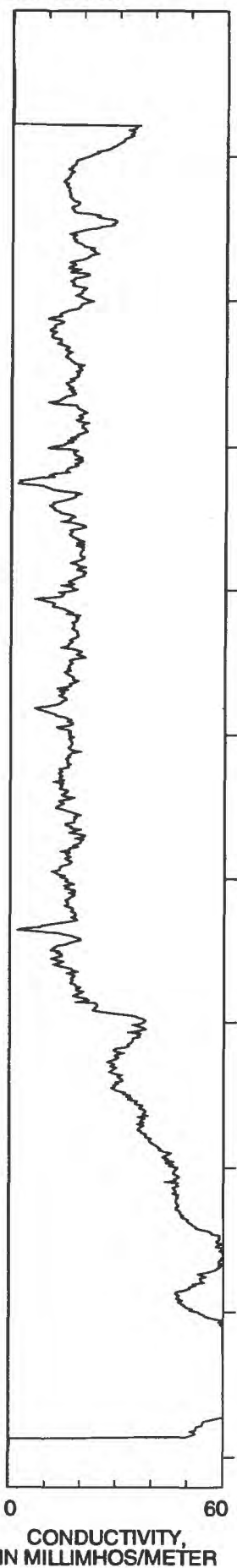

PIEZOMETER COMPLETION

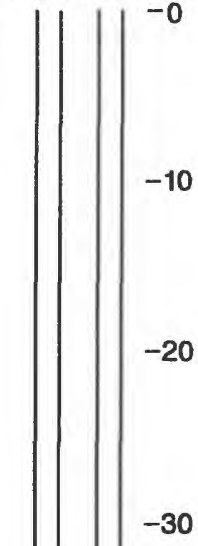

$-30$

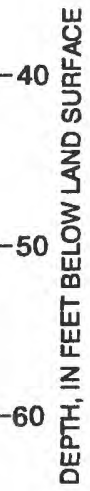

$-70$

$-80$

$-90$

SCREENED

INTERVAL

$-100$

PIEZOMETER

EXPLANATION

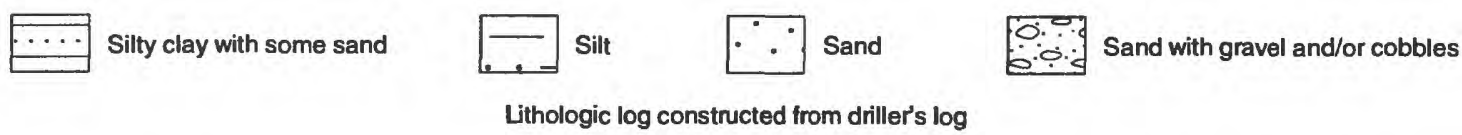

Figure 7.--Lithologic and geophysical logs and piezometer completion diagram for the Duranes Park site. 


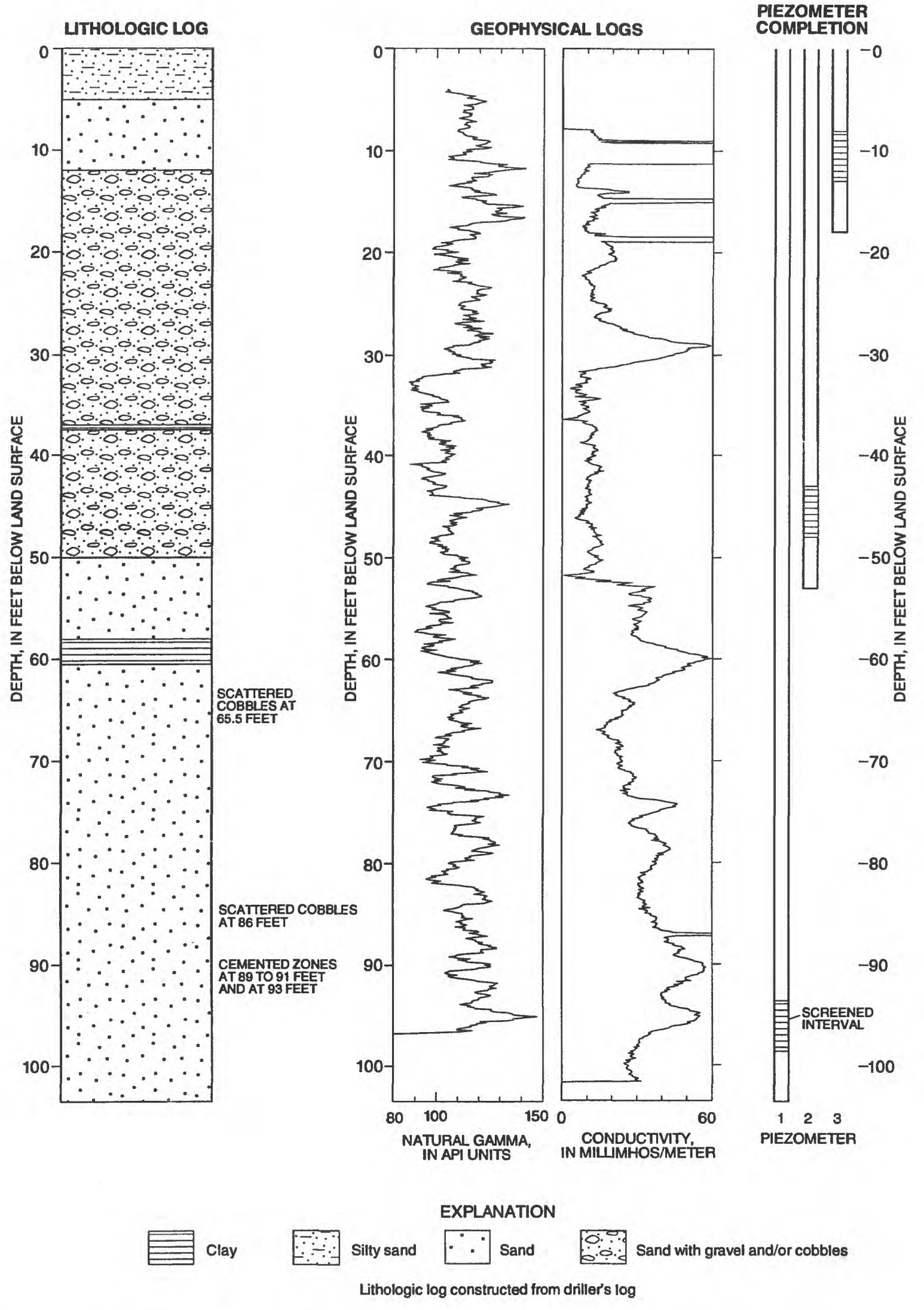

Figure 8.--Lithologic and geophysical logs and piezometer completion diagram for the Ricardo Road site. 